\title{
Role and fate of PML nuclear bodies in response to interferon and viral infections
}

\author{
Tarik Regad ${ }^{1}$ and Mounira K Chelbi-Alix*,1 \\ ${ }^{1}$ UPR 9045 CNRS, Institut André Lwoff, 7 rue Guy Moquet 94801, Villejuif, Cedex, France
}

Interferons (IFNs) are a family of secreted proteins with antiviral, antiproliferative and immunomodulatory activities. The different biological actions of IFN are believed to be mediated by the products of specifically induced cellular genes in the target cells. The promyelocytic leukaemia (PML) protein localizes both in the nucleoplasm and in matrix-associated multi-protein complexes known as nuclear bodies (NBs). PML is essential for the proper formation and the integrity of the NBs. Modification of PML by the Small Ubiquitin MOdifier (SUMO) was shown to be required for its localization in NBs. The number and the intensity of PML NBs increase in response to interferon (IFN). Inactivation of the IFN-induced PML gene by its fusion to retinoic acid receptor alpha alters the normal localization of PML from the punctuate nuclear patterns of NBs to microdispersed tiny dots and results in uncontrolled growth in Acute Promyelocytic Leukaemia. The NBs-associated proteins, PML, Sp100, Sp140, Sp110, ISG20 and PA28 are induced by IFN suggesting that nuclear bodies could play a role in IFN response. Although the function of PML NBs is still unclear, some results indicate that they may represent preferential targets for viral infections and that PML could play a role in the mechanism of the antiviral action of IFNs. Viruses, which require the cellular machinery for their replication, have evolved different ways to counteract the action of IFN by inhibiting IFN signalling, by blocking the activities of specific antiviral mediators or by altering PML expression and/or localization on nuclear bodies. Oncogene (2001) 20, 7274-7286.

Keywords: signalling; transcriptional repression; HFV; APL; SUMO; RBCC; TRIM

Interferons (IFNs) are a large family of multifunctional secreted proteins that regulate cellular antiviral, antitumour and immunological responses through IFNstimulated genes (ISGs) expression. IFNs are classified as $\alpha, \beta, \omega$ or $\gamma$ on the basis of their antigenic properties. Type I IFNs $(\alpha, \beta, \omega)$ are acid stable. They are produced in response to viral infection, double stranded (ds) RNA treatment or other stimuli (Stark et

*Correspondence: MK Chelbi-Alix; E-mail: mchelbi@infobiogen.fr al., 1998). IFN $\alpha$ species and IFN $\omega$ are products of leukocytes, whereas IFN $\beta$ is produced by fibroblasts. Another type I IFN, IFN $\tau$, has been described only in ungulate species. IFN $\gamma$ (type II) is acid labile. It is induced in T-lymphocytes and natural killer cells in response to antigens or mitogens (Pfeffer et al., 1998). Whether IFN is produced depends on the stimulus and the nature of the cell that is being stimulated.

\section{IFN signalling and increase in gene expression}

The biological activities of IFNs are initiated by binding to their cognate receptors. After interacting with different cell surface receptors, type I (predominantly $\alpha / \beta)$ and type II $(\gamma)$ IFNs, activate different signal cascades, known as the Jak/STAT pathways, leading to the transcription of a distinct set of genes which mediate the biological effects of these cytokines. The IFNs $\alpha / \beta$ - and IFN $\gamma$-inducible gene promoters are characterized by the presence of consensus elements, respectively the IFN-Stimulated Response Element (ISRE) -GAAAN(N)GAAA- and the IFN $\gamma$-activated site (GAS) -TTNCNNNAA-. Binding of both IFNs $\alpha / \beta$ and IFN $\gamma$ results in the differential activation of latent cytoplasmic factors, termed STATs (Signal Transducers and Activators of Transcription), which act at different cis-acting DNA elements. Tyk2 and Jak1 kinases play a key role in the induction of IFN $\alpha / \beta$ responsive genes and Jak1 and Jak2 in that of IFN $\gamma$ (Figure 1).

In response to IFN $\alpha / \beta$, Jak1 and Tyk2 phosphorylate Stat1, Stat2 and Stat3, leading to the formation of STAT homo- or heterodimers through mutual phosphotyrosine-Src homology region 2 (SH2) interactions (Pellegrini and Dusanter-Fourt, 1997; Schindler and Darnell, 1995). The IFN-Stimulated Gene Factor 3 (ISGF3) is formed by Stat1 and Stat2 (Stat1:2) in association with the DNA-binding protein, p48 (sometimes referred to IRF9), a member of the Interferon Regulatory Factor (IRF) family. ISGF3 as well as the complex between Stat1 homodimers and p48 bind to the ISRE. In addition, homo- and heterodimers of Stat 1 and Stat 3 (Stat $1: 1$, Stat $3: 3$ and Stat $1: 3$ ) bind to a palindromic version of the GAS, regulating the expression of distinct ISGs (Pine et al., 1994). In response to IFN $\gamma$, Jak1 and Jak2 phosphorylate only Stat1, forming homodimers that bind to the GAS motif. The transcription factor IRF-1, highly induced 


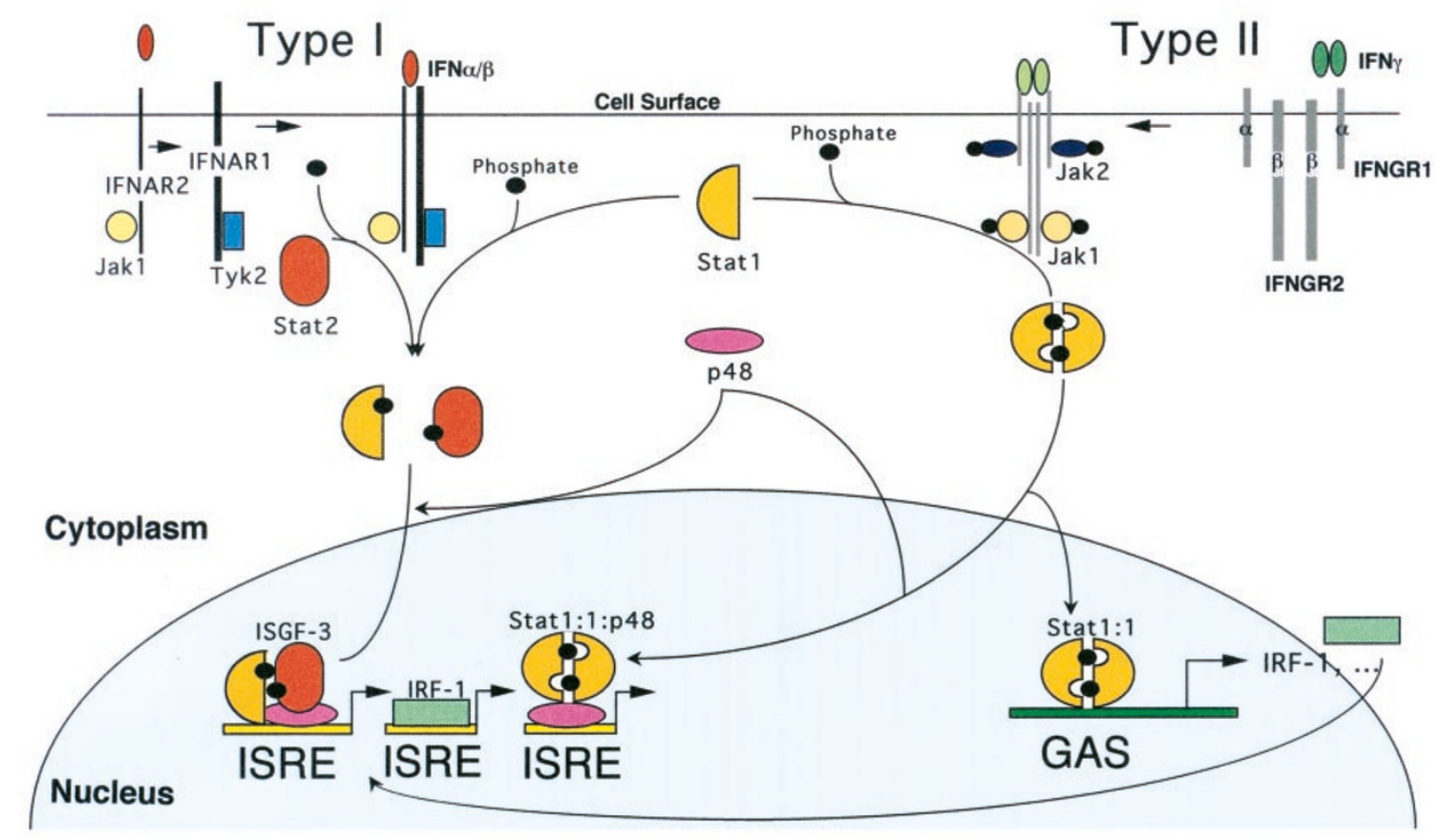

Figure 1 Mechanisms of gene activation by IFN. IFN $\beta$ and other type I IFNs compete for binding to the same receptor as IFN $\alpha$. IFN $\alpha$ and IFN $\gamma$ bind to different receptors. Two subunits of the IFN $\alpha$ receptor (IFNAR1 and IFNAR2) and two subunits of the IFN $\gamma$ receptor (IFNGR1 and IFNGR2) have been identified so far. Binding of IFN $\alpha$ to its receptor leads to tyrosine phosphorylation of two essential tyrosine kinases, Tyk2 and Jak1, which is followed by tyrosine phosphorylation of the STAT proteins, Stat1, Stat2, Stat3 (see text for details). Phosphorylated Stat1 and Stat2 translocate to the nucleus and in association with $\mathrm{p} 48$ form the ISGF3 complex that binds to the ISRE, present in most IFN $\alpha$ and IFN $\beta$-inducible genes. Binding of IFN $\gamma$ to its receptor leads to tyrosine phosphorylation of Jak1 and Jak2 resulting in phosphorylation of Stat1. Dimeric phosphotylated Stat1 translocates to the nucleus and binds to the GAS motif present in many IFN $\gamma$-inducible genes. IRF-1, highly induced by IFN $\gamma$ because of the presence of a GAS site in its promoter, has the property of binding the ISRE thus directly activating IFN $\alpha / \beta$ stimulated genes

by IFN $\gamma$ because of the presence of a GAS site in its promoter, has the property of binding the ISRE thus directly activating IFN $\alpha / \beta$-stimulated genes. This can explain in part the complex pattern of gene expression; for example, IFN $\gamma$ can induce the synthesis of genes that lack GAS sites via the induction of IRF-1 (Foss and Prydz, 1999). Characterization of these signalling pathways has provided some insights into the overlapping or synergistic effects of various IFNs.

The biological responses of IFNs are mediated by more than 100 proteins encoded by ISGs. Type I $(\alpha / \beta)$ and type II $(\gamma)$ IFNs have no structural homology. However, functional similarities exist due to a high overlap in the types of induced-genes (Stark et al., 1998). IFNs induce the transcription of a significant number of genes. Large-scale screening using oligonucleotide arrays has identified several novel humaninducible genes that are induced by either IFN $\alpha / \beta$ or IFN $\gamma$ or both (Der et al., 1998). Consequently, the physiological role of the majority of IFN-induced proteins has not been recognized yet.

\section{Nuclear bodies and the IFN response}

The nucleus contains a number of discrete macromolecular domains that coordinate a variety of nuclear processes. Among these domains are PML nuclear bodies (PML NBs). Pro-Myelocytic Leukaemia (PML) protein is expressed in the nuclear diffuse fraction of the nucleoplasm as well as in the NBs. The soluble nuclear fraction of PML is not SUMO-modified, while the insoluble fraction, PML NBs, remains modified. SUMO (Small Ubiquitin MOdifier) modification of PML is critical in maintaining the structure of the NBs (see review by $\mathbf{J}$ Seeler and A Dejean in this issue). PML is the organizer of the NBs (Ishov et al., 1999). Ablation of PML by homologous recombination shows that mice are viable but more susceptible to tumorigenesis and infections (Wang et al., 1998b), and that PML expression is essential for the ability of type I and II IFNs to induce programmed cell death (Wang et al., 1998a).

The function of PML NBs appears to be quite complex, with probable roles in cancer, apoptosis, and viral infections. These structures are highly dynamic, they recruit several proteins depending on different conditions i.e. transformation, stress, interferon treatment, viral infections. The list of cellular and viral proteins recruited on PML NBs, based on colocalization studies, are growing (see review by $\mathrm{D}$ Negorev and G Maul in this issue), those induced by IFNs will be discussed in this review.

There are six NB-associated proteins, identified to date, whose expression is increased by IFN treatment: 
PML, Sp100, Sp140, Sp110, ISG20 and PA28. Among these proteins, the IFN-induced PML and Sp100 share many properties. A large number of variant proteins is expressed from both genes because of extensive $\mathrm{COOH}$ terminal alternative splicing. A further common feature of both proteins is their conjugation to SUMO.

\section{$P M L$}

All IFNs $(\alpha, \beta$, and $\gamma)$ sharply induce PML expression leading to a marked swelling of the NBs (Chelbi-Alix et al., 1995; Lavau et al., 1995). PML mRNA induction by IFN $\alpha$ and IFN $\gamma$ is rapid, and the protein synthesis inhibitor cycloheximide fails to antagonize this, which is consistent with a direct activation of the gene (Stadler et al., 1995). Different forms of PML, arising from alternative splicing of a single gene (see review by $\mathrm{P}$ Freemont et al., in this issue), are induced by IFN in different cell lines. These different IFN-induced PML isoforms, having molecular weights ranging from $70-$ 130, can also represent forms modified by SUMO (Chelbi-Alix and de The, 1999; Chelbi-Alix et al., 1995). IFNs increase the expression of PML both in the nucleoplasm and in the NBs (Chelbi-Alix, unpublished results). Furthermore, in the PML promoter, the ISRE -GAGAATCGAAACT- and GAS -TTTACCGTAAGelements have been identified and they closely match the consensus sequences (see above). Peculiarly, the PML ISRE and GAS elements are situated in the untranslated first exon, rather than about $100-500 \mathrm{bp}$ upstream of the startpoint, as in all other genes previously found to harbour these elements. Binding of IFN-induced transcription factors to these elements has proved to be weak for the PML GAS, but strong for the PML ISRE, which also seems to contribute substantially to the IFN $\gamma$ response (Stadler et al., 1995). Deletion of the ISRE motif in the promoter abolishes the response to type I and considerably diminishes induction by type II IFN, whereas deletion of the GAS element only modestly alters the response to IFN $\gamma$. The latter may in part induce PML expression indirectly through an ISRE binding transcriptional activator, such as IRF-1. This demonstrates that PML is a primary target gene of type I and type II IFNs.

\section{Sp100}

Sp100 is an autoantigen that was originally identified in patients suffering from the auto-immune disease, primary biliary cirrhosis. Sp100 was the first NBsassociated protein shown to be induced by type I $(\alpha / \beta)$ and type II $(\gamma)$ IFNs (Guldner et al., 1992). High RNA levels are mainly due to an IFN-enhanced transcription rate of the Sp100 gene (Grötzinger et al., 1996). Transient expression studies with different constructs derived from the Sp100 promoter have identified an imperfect ISRE -ACTTTCACTTCTCT-, within the first nucleotides upstream of the major transcription start site. This site bound IRF-1 strongly but ISGF3 only weakly (Grötzinger et al., 1996). The GAS motif -TTCCAGGAA-, approximately 500 base pairs up- stream of the ISRE, confers both type I and type II IFNs inducibility. With the Sp100-GAS, three IFN $\beta$ inducible complexes representing homo- and heterodimers of Stat 1 and Stat3 (Stat 1:1, Stat 3:3 and Stat $1: 3$ ) and one IFN $\gamma$-inducible complex (Stat 1:1), are observed. The necessity of both ISRE- and GAS-Sp100 for primary IFN $\alpha / \beta$ inducibility combined with their separation by several hundred nucleotides, seems to be unique for the Sp100 promoter.

\section{Sp140}

Serum from a patient with primary biliary cirrhosis was used to identify a cDNA encoding a novel component of the NBs, a $140 \mathrm{kDa}$ protein designated Sp140 (Bloch et al., 1996). The amino-terminal portion of $\mathrm{Sp} 140$ is $49 \%$ identical to the amino-terminal region of Sp100. The carboxyl portion of Sp140 contains a plant homeobox domain and bromodomain; it is $39 \%$ identical to the carboxyl portion of murine nuclear hormone receptor transcription intermediary factor $1 \alpha$ $(T I F 1 \alpha)$. Sp140 is localized on the PML NBs in differentiated HL60 and NB4 cells (Bloch et al., 1996) and in resting cells (Bloch et al., 1999). However, it was reported that Sp140/LYSp100B, for LYSp100-associated nuclear dots (LANDs), appear to be distinct in location and morphology from PML NBs in Blymphocytic cell lines (Dent et al., 1996). Since Sp140/ LYSp100B is only expressed in lymphocytes, it has been postulated that LANDs function is a tissue-restricted manner. Expression of Sp140 is enhanced at mRNA and protein levels by IFN $\gamma$ (Bloch et al., 1996, 1999). However, Sp140 is associated with a subset of PMLSp100 NBs in IFN $\gamma$-treated cells (Bloch et al., 1999). Further experiments with Sp140 promoter are needed to confirm that Sp140 is a primary target gene of IFN $\gamma$.

\section{$\operatorname{Sp} 110$}

A cDNA encoding a leukocyte-specific NB component was designated Sp110 (Bloch et al., 2000). The Nterminal portion of $\mathrm{Sp} 110$ is homologous to two previously characterized components of the nuclear body (Sp100 and Sp140). The C-terminal region of Sp110 is homologous to the transcription intermediary factor 1 (TIF1) family of proteins. High levels of Sp110 mRNA were detected in human peripheral blood leukocytes and spleen but not in other tissues. As observed with $\mathrm{Sp} 100$ and $\mathrm{Sp} 140$, IFN $\gamma$ treatment enhances expression of Sp110. The levels of Sp110 mRNA and protein also increase in the NB4 cell line treated with all-trans retinoic acid (ATRA), this is not surprising because ATRA induces a high level of IFN in NB4 cells (Pelicano et al., 1999; Chelbi-Alix and Pelicano, 1999). Sp110 is localized in PML NBs in ATRA-treated NB4 cells.

\section{PA28}

PA28 (also known as the 11S regulator), a ring-shaped molecule composed of homologous $\alpha$ and $\beta$ subunits 
(Rechsteiner et al., 2000), is an IFN $\gamma$ inducible proteasome activator, required for presentation of certain major histocompatibility (MHC) class I antigens. IFN $\gamma$ increases the levels of both mRNA and protein for PA28 $\alpha$ and PA28 $\beta$ (Tanahashi et al., 1997). PA28 is localized in part on PML NBs, the punctuate number and size of the PA28 greatly increase upon IFN $\gamma$ treatment. Like PML, PA28 is delocalized from NBs in NB4 cells or by expression of the CMV protein, IE1. In contrast to PA28, the proteasome, functional target of PA28, is not detected on PML NBs in untreated cells. However, IFN $\gamma$ treatment results in recruitment of the 'immunoproteasome' (20S) on this structure (Fabunmi et al., 2001). The mechanisms that govern the regulated localization of PA28 and the proteasome in PML NBs are poorly defined. PA28 may assemble or activate immunoproteasome on PML NBs as part of its role in IFN $\gamma$ response and in proteasome-dependent MHC class I antigen presentation.

\section{ISG20}

A human cDNA, cloned in 1997, codes for a $20-\mathrm{kDa}$ protein sharing striking homology with the product of the Xenopus laevis XPMC2 gene. It has been referred to as ISG20 for interferon-stimulated gene product of $20 \mathrm{kDa}$. The ISG20 amino acid sequence does not enclose a canonic bipartite nuclear localization signal, but the presence of lysine- and arginine- rich domains and the small size of the protein have suggested that this protein might be targeted to the nucleus. Ectopic expression of a fusion protein between ISG20 and the HA epitope peptide reveals that ISG20 is predominantly nuclear and gives a punctuated staining pattern closely associated with PML NBs. However, no direct interaction was detected between these proteins and ISG20 by a yeast two hybrid study. The availability of specific antibodies against ISG20 is important to confirm the presence of endogenous ISG20 in PML NBs. ISG20 is strongly induced at the transcriptional level by type I IFN and, to a lesser extent, by type II IFN (Gongora et al., 1997). Its promoter contains an ISRE -GAAACTGGAAAC- motif which mediates induction by both type I and type II IFNs in the absence of a functional GAS. IRF-1 binds to the ISG20-ISRE forming a complex which appears performed with nuclear extracts from IFN type II treated cells in EMSA studies. Mutations in the ISRE result in the loss of IFN type I and type II inducibility of the luciferase reporter gene (Gongora et al., 2000). Interestingly, it has been reported that ISG20 is a $3^{\prime}$ to $5^{\prime}$ exonuclease in vitro with specificity for single stranded RNA and, to a lesser extent, for DNA (Nguyen et al., 2001). Notably, ISG20 is the second known RNase regulated by IFN, along with RNase L. In addition, over-expression of ISG20 confers resistance to infections by some RNA viruses ( $\mathrm{N}$ Mechti, personal communication). Given that ISG20 is an RNase induced by IFN, this suggests that it could represent a novel antiviral pathway in the mechanism of IFN action.

\section{Effects of IFN on APL cells}

PML-RAR $\alpha$ fusion transcripts and proteins are found in all Acute Promyelocytic Leukaemia (APL) patients whereas RAR $\alpha$-PML fusion transcripts, which are produced as a result of the $t(17 ; 15)$ reciprocal translocation, are detected in the majority but not all APL patients (Alcalay et al., 1992). Therefore, it is the PML-RAR $\alpha$ fusion, whose gene transcription is under the control of the PML promoter, rather than the RAR $\alpha-P M L$ protein, which most probably plays a crucial role in APL pathogenesis. The $t(15 ; 17)$ translocation disrupts one allele of the PML gene and consequently reduces its mRNA expression. Combined with the formation of heterodimers with PML/RAR $\alpha$, this facilitates sequestration of PML out of NBs. In APL, the chimeric PML-RAR $\alpha$ protein alters the normal localization of PML from the punctuate nuclear patterns of NBs to micro-dispersed tiny dots (Daniel et al., 1993; Dyck et al., 1994; Koken et al., 1994; Weis et al., 1994). Thus, inactivation of PML, an IFN-induced growth suppressor, may result in uncontrolled growth in APL.

In NB4 cells, a cell line bearing the $t(15 ; 17)$ translocation (Lanotte et al., 1991), IFN $\alpha$ treatment results in an increase of the micropunctuate pattern of PML, Sp100, and PML-RAR $\alpha$ without affecting their abnormal microspeckled localization (Chelbi-Alix et al., 1995). The IFN-induced PML-RAR $\alpha$ is accompanied by an enhanced sequestration of its heterodimeric partner RXR. This clear increase in the microspeckled RXR protein suggests that not all RXR is PML-RAR $\alpha$ associated prior to IFN treatment. IFN $\alpha$ may enhance RXR sequestration and could further impair nuclear receptor function, as previously proposed (Testa et al., 1994). PML-RAR $\alpha$ expression is also augmented by IFN in APL blasts from patients (Nason-Burchenal et al., 1995). The in vivo and in vitro anti-tumour effectiveness of IFNs is well documented, the demonstration that type I and II IFNs upregulate PML-RAR $\alpha$ in APL cells means that caution is necessary in the use of these cytokines in APL because they may accelerate the patient's leukaemia.

\section{IFN-induced proteins implicated in the antiviral state}

The establishment an antiviral state in cells is the defining activity of IFNs as well as the property that permitted their discovery. Their essential antiviral role has been demonstrated by a drastic increase in sensitivity to virus infections of mice lacking both IFN $\alpha / \beta$ and $\gamma$ receptors. Both types of IFN stimulate an antiviral state in target cells, whereby the replication of a virus is blocked or impaired due to the induction of a number of proteins that interfere with viral processes.

Any stage in virus replication may be a target for inhibition by IFNs, including entry, transcription, RNA stability, initiation of translation, maturation, 
assembly and release (reviewed in Stark et al., 1998). All activities of IFNs are believed to be mediated by IFN-regulated cellular proteins. Although the physiological functions of the majority of IFN-induced proteins remain unclear, several of them, namely the Protein Kinase RNA-dependent (PKR), the 2'5' oligoadenylate $\left(2^{\prime} 5^{\prime} \mathrm{A}\right)$ synthetase, certain $\mathrm{Mx}$ proteins and PML, have been shown to display intrinsic antiviral activities (Chelbi-Alix et al., 1998; Regad et al., 2001; Stark et al., 1998). Recent studies involving the generation of mice that are triply deficient in RNase $\mathrm{L}, \mathrm{PKR}$ and $\mathrm{Mx} 1$ indicate that there are additional antiviral effects of IFNs (Zhou et al., 1999). Both 2'5'A synthetase and PKR pathways lead to the inhibition of protein synthesis, they require double stranded (ds) RNA for their activation. The necessary activation of the IFNinduced PKR and $2^{\prime} 5^{\prime} \mathrm{A}$ synthetase is thought to be performed by viral ds RNA, produced as an intermediate of virus replication.

\section{The 2'5'A synthetase/RNase L pathway}

IFNs induce the synthesis of a family of enzymes, called $2^{\prime} 5^{\prime} \mathrm{A}$ synthetases, they are inactive in the absence of the only known cofactor, ds RNA. After being activated by ds RNA, the $2^{\prime} 5^{\prime} A$ synthetase catalyses the synthesis, from ATP, of the unusual 2'5' linked oligoadenylates $\left(2^{\prime} 5^{\prime} \mathrm{A}\right)$, with a general formula pppA $\left(2^{\prime} 5^{\prime} \mathrm{A}\right) \mathrm{n}$, where $\mathrm{n}$ is 1 to 4 . The $2^{\prime} 5^{\prime} \mathrm{A}$ in turn activate a latent cellular endonuclease named RNase L which degrades mRNAs. The $2^{\prime} 5^{\prime} \mathrm{A}$ are therefore a potent inhibitor of translation, and so the $2^{\prime} 5^{\prime} \mathrm{A}$ system, i.e. $2^{\prime} 5^{\prime} \mathrm{A}$ synthetase, $2^{\prime} 5^{\prime} \mathrm{A}$ and RNase $\mathrm{L}$, form part of the cascade of events involved in the antiviral actions of IFNs (Sen and Ransohoff, 1993). The only known function of the $2^{\prime} 5^{\prime} \mathrm{A}$ is to activate the RNase $\mathrm{L}$ responsible for degradation of viral and cellular singlestranded RNA. The action of $2^{\prime} 5^{\prime} \mathrm{A}$ in cells is transient because $2^{\prime} 5^{\prime} \mathrm{A}$ are degraded to AMP and ATP by $2^{\prime} 5^{\prime}$ phosphodiesterase (reviewed in Player and Torrence, 1998).

Overexpression of the $2^{\prime} 5^{\prime} \mathrm{A}$ synthetase is sufficient to inhibit picornaviruses such as mengo and encephalomyocarditis (EMCV) viruses but not vesicular stomatitis virus (VSV) or herpes simplex virus-2 (Chebath et al., 1987; Coccia et al., 1990). However, a high expression of the $2^{\prime} 5^{\prime} \mathrm{A}$ synthetase protein is not effective if the endogeneous level of RNase $\mathrm{L}$ is too low (Kumar et al., 1988) or if RNase L function is blocked by a dominant negative mutant (Hassel et al., 1993). RNase L-null mice are deficient in the antiEMCV effect of IFN $\alpha$ (Zhou et al., 1997). Inducible expression of the $2^{\prime} 5^{\prime} \mathrm{A}$ synthetase/RNase L system results in inhibition of vaccinia virus replication (DiazGuerra et al., 1997). Strong inhibition of HIV-1 replication has also been observed in cells stably transfected with a $2^{\prime} 5^{\prime} \mathrm{A}$ synthetase expression vector, driven by the HIV-1 long terminal repeats (LTR) (Schroder et al., 1990).

\section{ds RNA-dependent protein kinase}

The PKR (Protein Kinase RNA-dependent) protein has two well-characterized regions: the N-terminal contains the ds RNA binding site and the C-terminal contains all the conserved motifs for protein kinase activity. The PKR kinase is a serine-threonine-specific kinase that acquires catalytic activity only after activativation by autophosphorylation. After activation, the PKR catalyses the phosphorylation of at least five protein susbstrates; the $\alpha$ subunit of the eucaryotic translation initiation factor eIF2, the PKR itself, the transcription factor inhibitor I-kappa $\mathrm{B}$, histones and an unidentified $90 \mathrm{kDa}$ protein. eIF $2 \alpha$ remains the most well-characterized physiological substrate for PKR. Phosphorylation of eIF2, at serine residue 51, by PKR leads to a block in the exchange of eIF2bound GDP with GTP eIF-2B, resulting in a shut-off of translation at the initiation step (reviewed in Gale and Katze, 1998). Viral replication can produce highly structured viral transcripts in the form of ds RNA that can bind to and activate PKR, which then phosphorylates eIF $2 \alpha$.

The involvement of PKR in the antiviral effects of IFNs is suggested by the existence of several inhibitors of this enzyme, which are either encoded or induced by various viruses. Detectable levels of PKR are present in most cells even without IFN treatment, and phosphorylation of PKR and eIF2 have been observed in many virus infected cells, suggesting that PKR activation by viral ds RNA may also be involved in the shut-off of host protein synthesis in virus-infected cells. Overexpression of PKR inhibits EMCV replication (Meurs et al., 1992). HIV-1 replication has been reported to be inhibited in SupT1 cells transduced with an HIV LTRdriven PKR cDNA construct (Adelson et al., 1999). In promonocytic U-937 cells, expression of a dominant negative PKR mutant or an antisense PKR cDNA construct suppresses the anti-EMCV effect of IFN $\alpha$ and IFN $\gamma$ (Der and Lau, 1995). IFN $\gamma$ treatment prolongs the survival of wild-type but not PKR-null mice after infection with EMCV (Yang et al., 1995), whereas IFN $\alpha$ prolongs the survival equally in both types of mice, suggesting that other IFN-induced antiviral pathways are involved.

\section{Mx protein}

Mx proteins are found in all IFN-treated vertebrate cells, but only some of these proteins have been shown to possess antiviral activity against influenza and other negative-strand RNA viruses at the level of viral transcription and at other steps. Mx proteins seem to be organized in two functional domains; an N-terminal regulatory domain and a $\mathrm{C}$-terminal effector domain. In the $\mathrm{N}$-terminal region, the protein have three sequence elements characteristic of guanosine-5'-triphosphate (GTP)-binding proteins. The Mx proteins bind and hydrolyse GTP. GTPase activity seems to be necessary for their antiviral actions (reviewed in 
Staeheli et al., 1993). The C-terminal region of $\mathrm{Mx}$ proteins contains two highly conserved leucine zipper motifs probably implicated in protein - protein interactions. The Mx C-terminal region may be implicated in direct interaction with viral target structures. The two known human Mx proteins (MxA and MxB) (Pavlovic et al., 1990), like rat (Mx2 or $\mathrm{Mx} 3)$ (Meier et al., 1988) and mouse Mx2 (Zürcher et al., 1992a) are cytoplasmic. The Mx1 protein has a speckled nuclear localization in both mouse and rat cells (Arnheiter and Meier, 1990; Meier et al., 1988; Zürcher et al., 1992b). Interestingly, we have shown previously that the nuclear organelles harbouring $\mathrm{Mx} 1$ are associated with or juxtaposed to PML NBs (Chelbi-Alix et al., 1995). While rat Mx3 or human $\mathrm{MxB}$ are devoid of antiviral properties, rat $\mathrm{Mx} 1$ and human $\mathrm{MxA}$ are active against both VSV and influenza virus (Staeheli et al., 1993). In addition, MxA also confers resistance to measles, Thogoto, bunya, phlebo, hanta and human parainfluenza 3 viruses. Mouse Mxl confers resistance to influenza, Thogoto and tick-born Dhori viruses, but Mx2 (mouse or rat) protects against VSV only. Interestingly, in the case of influenza virus, which replicates in the nucleus of infected host cells, it has been shown that the nuclear mouse $\mathrm{Mx} 1$ protein interferes with the process of primary transcription of influenza virus, most likely by disturbing the polymerase function. In contrast, the cytoplasmic human MxA protein blocks influenza virus replication at a post-transcriptional step that is still ill-defined. Many viruses that are blocked by $\mathrm{Mx}$ do not have many properties in common, all are enveloped singlestranded RNA viruses, but their replication strategies are quite distinct (review Haller et al., 1998).

\section{PML}

Initial studies have shown that PML is matrix bound and NBs-associated, later it was shown that a significant fraction of PML is present in the nucleoplasm, most likely on chromatin. Only a small fraction of PML is NB-associated, at least in PML over-expressing and in IFN-treated cells. PML protein contains several important functional domains which together form the RBCC/TRIM motif, a C3HC4 (RING finger) zinc binding motif, two other cysteine/histidine-rich motifs, the B boxes (B1 and B2), an $\alpha$-helical coiled-coil region. In addition, PML contains a nuclear localization signal (NLS). The RBCC/TRIM motif is important for the localization of PML within the NBs for heterointeractions leading to growth suppressor, apoptotic and antiviral properties (Borden et al., 1995, 1997; Chelbi-Alix et al., 1996, 1998; Regad et al., 2001) (see review by $\mathrm{P}$ Freemont in this issue).

Over-expression of PML inhibits VSV and influenza virus replication

Over-expression of PML III confers resistance against VSV and influenza virus (Chelbi-Alix et al., 1998).
PML protein has an inhibitory effect on both VSV mRNA and protein synthesis. Inhibition of viral multiplication is dependent on both levels of PML expression and multiplicity of infection (MOI) and reaches 100 fold. The highest degree of inhibition of VSV or influenza virus replication is observed at a low multiplicity of infection (MOI) of 0.1 . When compared to MxA protein, PML was found to have a less powerful antiviral activity against VSV and influenza virus. Moreover, the resistance to VSV and EMCV infections (at a MOI of 1) conferred by IFN was similar in embryonic fibroblasts derived from mice with PML knocked-out and from wild type mice (Lavau et al., 1995). This is not surprising for EMCV, as overexpression of PML does not affect the replication of this virus (Chelbi-Alix et al., 1998). For VSV, Mx2 (Zürcher et al., 1992a) appears to play a major role which may mask the PML contribution having only a low antiviral effect at a MOI of 1 (Chelbi-Alix et al., 1998).

Influenza virus whose replication and transcription are nuclear, and VSV, whose replication takes place entirely in the cytoplasm, are both inhibited by PML wild-type and by cytoplasmic PML mutant (PML1381). How PML might inhibit VSV and influenza virus replication is not known yet. PML closely resembles rat $\mathrm{Mx} 1$ as to its localization as well as antiviral properties. These unexpected results suggest that PML protein could inhibit virus multiplication indirectly by modifying other cellular proteins which then modulate viral replication in the relevant cellular compartment.

\section{PML confers resistance to Human Foamy virus (HFV)}

Foamy viruses (FVs) are complex animal retroviruses encoding auxiliary proteins from the $3^{\prime}$ end of their genome in addition to the structural and enzymatic $g a g$, pol and env genes. In the case of the HFV, the prototype of FVs also called PVF-1, two additional open reading frames have been described, ORF1 (encoding a protein called Tas) and ORF2 (for review, Lecellier and Saib, 2000). Tas (for transactivator of spumaviruses), is a $36 \mathrm{kDa}$ nuclear phosphoprotein, which transactivates viral gene expression by directly binding to the LTR and an internal promoter ( $\mathrm{He}$ et al., 1996). The latter is located upstream of the auxiliary genes, $3^{\prime}$ of the env gene, and directs their expression early in the replication cycle. As most viral transactivators, Tas harbours distinct autonomous domains which are implicated in DNA binding (residues 88 to 200) and transactivation (residues 272 to 300). Recent works have reported that the FVs, although harbouring most of the retroviral characteristics (as found in HIV, HTLV-I), possess several properties relating them to Hepatitis B virus (HBV), such as the formation of a specific pol mRNA and the infectivity of the viral DNA contained in extra-cellular virions. Moreover, as for $\mathrm{HBV}$, reverse transcription of FV genomes occurs during the late phase of infection (Linial, 1999).

Over-expression of PML III, but not that of Mx1 or MxA, confers resistance to HFV. The degree of 
inhibition of HFV replication by PML is similar to that obtained in control cells treated with 1000 units $/ \mathrm{ml}$ of IFN $\alpha$. This effect reflects a decrease of viral mRNA, DNA, protein synthesis and Reverse Transcriptase activity. PML expression in transfected and IFNtreated cells inhibits Tas-mediated transactivation of the HFV LTR and the internal promoter. Note that the expression of the human PKR or the catalytically inactive form of PKR (PKR K-R296) (Meurs et al., 1995) does not affect Tas-mediated transactivation of the HFV LTR (result cited in Regad et al., 2001). The role of PML in the IFN-induced antiviral action against HFV is further demonstrated by the inability of IFN to inhibit HFV replication and to diminish Tas-mediated LTR transactivation in murine embryonic fibroblasts MEF $\mathrm{PML}^{-1-}$. Introducing PML into this cell line by transient expression represses transactivation in a dose-dependent manner (Regad et al., 2001).

The nuclear localization of PML and its RING domain, but not its coiled-coil domain or its modification by SUMO, are necessary for the repression of transcription. From the nuclear diffuse compartment or from the NBs, PML exerts repression via its interaction with the $\mathrm{N}$-terminal region of Tas. PML interacts physically with Tas, inhibits its binding to HFV LTR and IP, and consequently reduces Tas-stimulated viral transcription (Figure 2). As far as we know, PML is the first example of an IFN-induced protein that inhibits the function of a viral transactivator through a physical interaction.

In wild-type MEF, IFN $\alpha$ inhibits viral protein synthesis, this effect is almost completely abrogated in $\mathrm{PML}^{-/-}$MEF suggesting that PML could play a key role in mediating the IFN-induced antiviral state against HFV. PML is not able to decrease the transactivation of HIV-1 or HTLV-1 expression by Tat or Tax respectively, whereas transactivation of HIV -1 by Tas is reduced by $64 \%$ (result cited in Regad et al., 2001). However, it remains to be investigated whether PML can interfere with the replication of HIV-1 or HTLV-I through other mechanisms.

\section{Viral strategies to counteract the IFN response}

\section{General mechanisms of viral disruption of IFN actions}

Viruses, which require the cellular machinery for their replication, have evolved different ways to counter the actions of IFNs (reviewed in Goodbourn et al., 2000; Stark et al., 1998). They have developed strategies altering IFN signalling, IFN-induced mediators such as $2^{\prime} 5^{\prime} \mathrm{A} / \mathrm{RNase} \mathrm{L}$, PKR (Table 1) or PML NBs (Sternsdorf et al., 1997) (Table 2).

The adenovirus E1A protein disrupts the response to both IFN $\alpha / \beta$ and IFN $\gamma$ at the level of signal transduction by decreasing the p48 level (Leonard and Sen, 1997) and interacting directly with Stat 1 (Look et al., 1998). Adenovirus produces short RNA molecules (VAI RNA) that can form a secondary structure interacting with the ds RNA-binding site on PKR and acting as a competitive inhibitor (Sharp et al., 1993).

EBV also encodes two small RNAs, EBR-1 and EBR-2, that may interfere with PKR activity (Sharp et al., 1993). By decreasing Jak1 and p48 levels by a proteasome-dependent mechanism, human cytomegalovirus (HCMV) disrupts signal transduction of both type I and II IFNs (Miller et al., 1998, 1999). HSV-1 infection targets both $2^{\prime} 5^{\prime} \mathrm{A} / \mathrm{RNase} \mathrm{L}$ and PKR. The ICP34.5 of HSV-1 functions to prevent the shut-off of

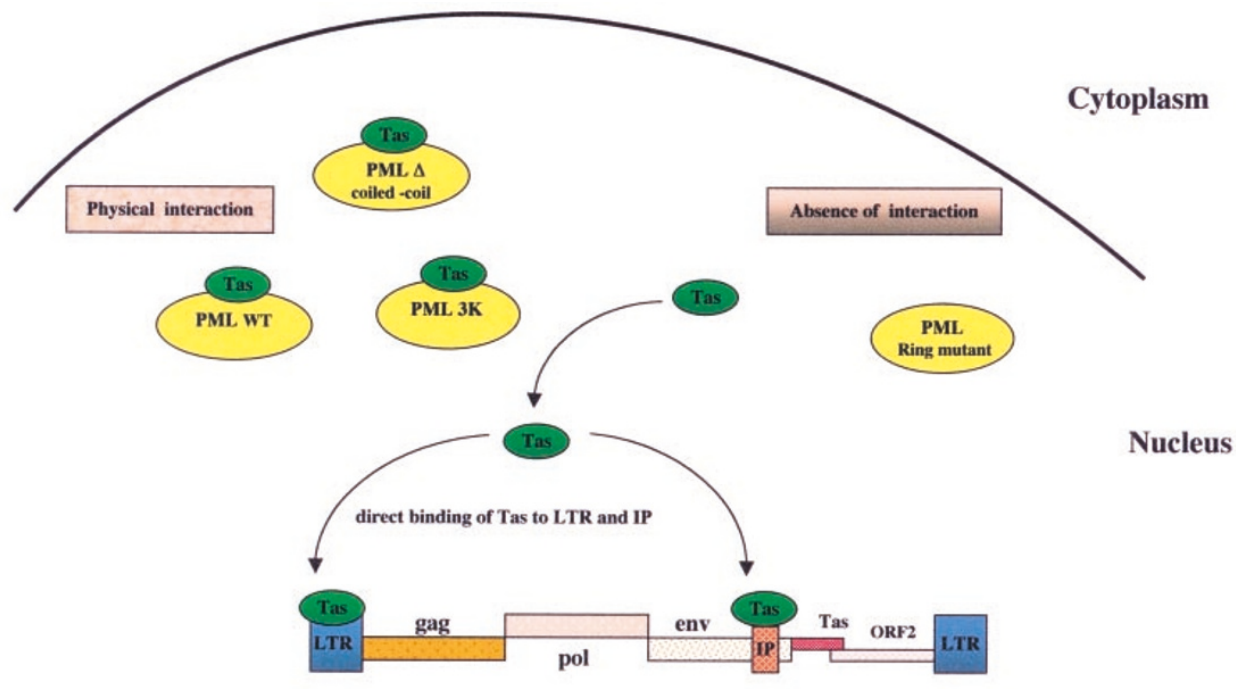

Figure 2 PML interacts physically with Tas inhibiting Tas-induced LTR and IP transactivations. Tas transactivates viral gene expression by directly binding to the LTR and an internal promoter (IP). PML wild-type, the PML coiled-coil mutant (PML $216-$ 333) and the unsumoylated PML 3K mutant interact directly with Tas and repress Tas-induced LTR and IP transactivations. In contrast, PML RING finger mutant do not interact with Tas and has no effect on the transactivation of LTR and IP by Tas 
Table 1 Virus inhibition of IFN actions

\begin{tabular}{|c|c|c|c|}
\hline Virus & Targets & Mechanism of action & References \\
\hline \multirow[t]{3}{*}{ Adenovirus } & P48 & E1A reduces p48 level & Leonard and Sen, 1997 \\
\hline & Stat1 & E1A interacts with Stat1 & Look et al., 1998 \\
\hline & PKR & Inactivation by VAI RNA & Sharp et al., 1993 \\
\hline HCMV & Jak1, p48 & Reduces level of Jak1 and p48 & Miller et al., 1998, 1999 \\
\hline \multirow[t]{3}{*}{ HSV-1 } & PKR & Us11 inhibits PKR activation & Poppers et al., 2000 \\
\hline & & ICP34.5 required to dephosphorylate elF $2 \alpha$ & Cheng et al., 2001 \\
\hline & RNase L & Inactivates $2^{\prime}-5^{\prime} \mathrm{A}$ analogs & Cayley et al., 1984 \\
\hline \multirow[t]{3}{*}{ HHV-8 } & IRF-1 & Virus IRF homologue blocks transcriptional responses & Zimring et al., 1998 \\
\hline & & to IFN $\alpha, \beta, \gamma$ & Buryseck et al., 1999 \\
\hline & PKR & vIRF-2 interacts with PKR & Buryseck and Pitha, 2001 \\
\hline HPV 16, 18 & $\mathrm{P} 48$ & E7 binds to $\mathrm{p} 48$ and blocks IFN $\alpha / \beta$ signalling & Barnard and McMillan, 1999 \\
\hline HPV 18 & Tyk2 & E6 associates Tyk2 and impairs Jak-Stat activation & Li et al., 1999 \\
\hline \multirow[t]{2}{*}{$\mathrm{HCV}$} & PKR & NS5 binds to PKR and inhibits its activity & Gale et al., 1999 \\
\hline & PKR & E2 inhibits PKR activity & Taylor et al., 1999 \\
\hline \multirow[t]{2}{*}{ Vaccinia virus } & PKR & E3L binds ds RNA and PKR & Sharp et al., 1998 \\
\hline & & K3L binds PKR & Sharp et al., 1997 \\
\hline Poliovirus & PKR & Induces PKR degradation & Black et al., 1989 \\
\hline Reovirus & PKR & Sigma 3 inhibits PKR activation & Imani and Jacob, 1999 \\
\hline \multirow[t]{2}{*}{ Influenza virus } & PKR & NS1 inhibits PKR activation & Bergmann et al., 2000 \\
\hline & PKR & Induction of cellular inhibitor p58 (IPK) & Melville et al., 1999 \\
\hline \multirow[t]{2}{*}{ HIV-1 } & PKR & PKR inactivation by Tat & Gunnery et al., 1990 \\
\hline & RNase L & $\begin{array}{l}\text { Induces RNase } \mathrm{L} \text { inhibitor that counteracts } 2^{\prime}-5^{\prime} \text { binding } \\
\text { to RNase L }\end{array}$ & Martinand et al., 1999 \\
\hline
\end{tabular}

Table 2 Virus alteration of PML nuclear bodies

\begin{tabular}{|c|c|c|c|}
\hline Virus & Targets & Mechanism of action & References \\
\hline \multirow[t]{2}{*}{ Adenovirus } & PML & E4-ORf3 disrupts NBs & Carvalho et al., 1995 \\
\hline & & & Puvion-Dutilleul et al., 1995, 1999 \\
\hline \multirow[t]{2}{*}{ HSV-1 } & PML & ICP0 delocalizes PML and Sp100 from & Everett et al., 1998, Everett, 1999 \\
\hline & Sp 100 & NBs and induces their degradation & Chelbi-Alix and de Thé, 1999 \\
\hline \multirow{2}{*}{$\mathrm{HCMV}$} & PML & IE1 disrupts PML NBs and causes reduced & Ahn et al., 1998 \\
\hline & & SUMO-1 modification of PML & Muller and Dejean, 1999 \\
\hline \multirow[t]{2}{*}{ EBV } & PML & EBNA5 colocalizes with PML NBs & Szekely et al., 1996 \\
\hline & & BZLF1 disrupts PML NBs & Bell et al., 2000b \\
\hline Papillomavirus & PML & L2 colocalizes with PML NBs and recruits L1 and E2 & Day et al., 1998 \\
\hline HDV & PML & L-HDAg alters PML NBs & Bell et al., 2000a \\
\hline HFV & PML & Tas colocalizes with PML NBs & Regad et al., 2001 \\
\hline HTLV-1 & Int-6 & $\begin{array}{l}\text { Tax delocalizes the NBs-associated } \\
\text { Int- } 6 \text { to the cytoplasm }\end{array}$ & Desbois et al., 1996 \\
\hline LCMV & PML & $\mathrm{Z}$ protein delocalizes PML from NBs to the cytoplasm & Borden et al., 1998b \\
\hline Rabies virus & PML & $\mathrm{P}$ protein delocalizes PML from NBs to the cytoplasm & Blondel et al., manuscript in preparation \\
\hline
\end{tabular}

protein synthesis mediated by PKR. ICP34.5 interacts with cellular protein phosphatase $1 \alpha$ (PP1), leading to dephosphorylation and hence reactivation of eIF $2 \alpha$. The AlaArg motif in the carboxyl terminus of ICP34.5 is required for the formation of a high-molecularweight complex that dephosphorylates eIF2 $\alpha$ (Cheng et al., 2001). The HSV-1 Us11 encodes an RNA binding protein that also prevents PKR activation (Poppers et al., 2000). Infection with HSV-1 leads to the formation of $2^{\prime} 5^{\prime}$ oligoadenylate analogues of as yet undetermined structures (Cayley et al., 1984), which impair the activation of the RNase L by authentic $2^{\prime} 5^{\prime}$ oligoadenylates.

Human herpes virus 8/Kaposisarcoma-associated virus (HHV-8/KSHV) encodes four open reading frames that show homology with the transcription factors of the IRF family. Three of them, viral IRF1 (vIRF-1), vIRF-2, and vIRF-3, have been cloned. VIRF-1 inhibits responses to type I and type II IFNs and blocks IRF-1 mediated transcription (Burysek et al., 1999; Zimring et al., 1998). Over-expression of vIRF-2 inhibited the antiviral effect of IFN and rescued translation of VSV mRNA from the IFNinduced translation block. VIRF-2 physically interacts with PKR consequently inhibiting auto-phosphorylation of PKR and thus blocking phosphorylation of eIF2 $\alpha$ (Burysek and Pitha, 2001).

Human papilloma virus (HPV), types 16 and 18 , E7 oncoprotein interacts directly with p48. Moreover, in the presence of E7, p48, the DNA-binding component of ISGF3, is unable to translocate to the nucleus upon IFN $\alpha$ treatment (Barnard and McMillan, 1999). In addition, HPV, type 18, E6 oncoprotein physically associates with Tyk2 and impairs Jak-STAT activation by IFN $\alpha$ (Li et al., 1999). IFN $\alpha$ is used in the treatment of HPV infections, yet in vivo data suggest that the virus has developed mechanisms to avoid the effect of 
IFN. By targeting p48 and Tyk2, HPV abrogates signalling mediated by IFN $\alpha$.

Hepatitis $\mathrm{C}$ virus (HCV) infection blocks the transcriptional response to IFN $\alpha / \beta$ and IFN $\gamma$ (Heim et al., 1999). HCV encodes the non structural protein NS5A, which binds PKR directly, thus inhibiting its activity (Gale et al., 1999). Furthermore, the HCV envelope protein E2 contains a sequence, identical to phosphorylation sites of PKR and eIF2 $\alpha$. E2 inhibits the kinase activity of PKR and blocks its effect on protein synthesis (Taylor et al., 1999).

Two vaccinia virus gene products, E3L and $\mathrm{K} 3 \mathrm{~L}$, target PKR. The E3L gene product is a ds RNA binding protein that prevents activation of PKR (Sharp et al., 1998). Homologous regions of the vaccinia virus $\mathrm{K} 3 \mathrm{~L}$ gene product and eIF $2 \alpha$ interact with the same domain within the PKR, thus this viral protein binds to PKR reducing its ability to interact with phosphorylated eIF2 $\alpha$ (Sharp et al., 1997).

In addition to directly interacting with PKR or to binding ds RNA, viral gene products can inhibit this enzyme by inducing its degradation, as reported for poliovirus infection (Black et al., 1989).

Reovirus encodes sigma 3 protein which inhibits PKR activation. The ds RNA binding of the viral protein seems to be necessary for the kinase inhibitory effect (Imani and Jacobs, 1988).

Influenza virus NS1 inhibits PKR activation, an effect not observed with virus mutant with a defective NS1 protein (Bergmann et al., 2000; Hatada et al., 1999). Interestingly, influenza virus infection induces the activation of a cellular inhibitor of PKR termed P58 (IPK) (Melville et al., 1999). IPK inhibits PKR through direct protein-protein interaction, and this protein has been identified as the molecular chaperone hsp40. Thus, regulation of PKR activity occurs by recruiting a cellular stress protein.

Human immunodeficiency virus type 1(HIV-1) infection targets both RNase L and PKR. HIV-1 (Martinand et al., 1999) induces RNase L inhibitor (RLI) that counteracts $2^{\prime} 5^{\prime} \mathrm{A}$ binding to RNase L and hence prevents its activation. Over-expression of RLI causes a decrease in RNase L activity and a twofold enhancement of HIV production (Martinand et al., 1999) suggesting the involvement of RLI in the inhibition of $2^{\prime} 5^{\prime} \mathrm{A} / \mathrm{RNase} \mathrm{L}$ observed during HIV-1 infection.

HIV-1 produces a Tat-response region (HIV TAR) RNA that prevents PKR activation (Gunnery et al., 1990). In addition, HIV-1 Tat protein, an activator of viral transcription, can associate with PKR in vitro and in vivo and inhibit PKR activity by both RNAdependent and RNA-independent mechanisms (Cai et al., 2000).

\section{Virus alteration of PML nuclear bodies}

Many studies have shown that early during the viral infection, different viral proteins transiently colocalize with PML and Sp100 on NBs before disrupting them (reviewed Sternsdorf et al., 1997). The functional consequences of the altered NB-antigens localization are not known. In particular, it is not clear whether this is a consequence of nuclear reorganization in response to infection or a specific viral strategy to block cellular systems that may hamper viral replication. DNA viruses from different families alter the localization and/or the expression of PML NBs such as HSV-1 (Chelbi-Alix and de The, 1999; Everett et al., 1998; Maul and Everett, 1994), human cytomegalovirus (HCMV) (Ahn et al., 1999; Muller and Dejean, 1999), adenovirus (Carvalho et al., 1995; Puvion-Dutilleul et al., 1995, 1999) EBV (Bell et al., 2000b; Szekely et al., 1996) or Papilloma virus (Day et al., 1998) (Table 2). In HCMV infection, the major immediate-early proteins IE1 targets PML NBs and causes a redistribution of PML from the NBs into a nuclear diffuse form. Disruption of PML NBs by IE1 correlates with efficient early stages of viral gene expression and DNA replication in HCMV infection (Ahn and Hayward, 2000). In contrast to HSV-1 ICP0, HCMV IE1 does not induce PML degradation but reduces PML modification by SUMO (Muller and Dejean, 1999).

PML NBs could represent early sites of viral transcription and replication, the recent advances in the study of interactions between DNA viruses and PML NBs are reviewed by $\mathrm{R}$ Everett in this issue.

Concerning RNA viruses, the replication of some of them, VSV, influenza virus and HFV, is inhibited by overexpression of PML, and in other cases RNA viral gene products colocalize or disrupt PML NBs.

\section{Hepatitis delta virus}

Hepatitis Delta Virus (HDV) is a small RNA virus found in nature. It is associated solely with human hepatitis B virus (HBV). The co-infection with HDV often increases the severity of HBV-associated liver disease. HDV bears a single coding region whose product, the hepatitis delta antigen (HDAg), is expressed during viral infection in two isoforms, small (S-HDAg) and large (L-HDAg). SHDAg is required for replication, while L-HDAg is inhibitory to it and necessary for the envelopment of the HDV genomic RNA by hepatitis B virus proteins. During HDV infection L-HDAg colocalizes with PML NBs. In this structure, PML is found in the rims with L-HDAg and viral RNA, while the known NBs components Sp100, Daxx and NDP55 are found in the centre of the NBs (Bell et al., 2000a). The observation that the viral component linked to repression of replication can associate with PML, suggests that this protein could play a role in the regulation of HDV RNA synthesis. Analysing the molecular interaction of L-HDAg with NBs-associated proteins in relation with the viral RNA should shed more light on these processes. 


\section{The human T cell leukaemia virus type1}

The human T cell leukaemia virus type1 (HTLV-1) Tax oncoprotein (Desbois et al., 1996) alters NB-associated Int- 6 protein localization. The binding of Tax to Int- 6 causes its redistribution from PML NBs to the cytoplasm without affecting the localization of PML (Desbois et al., 1996). Int-6, a $52 \mathrm{kD}$ protein, was shown to interact with the NBs-associated protein Rfp. The interaction of Rfp with Int-6 is mediated through a region in $\mathrm{Rfp}$ designated 'Rfp domain', distinct from that involved in the interaction with PML (MorrisDesbois et al., 1999), suggesting that Rfp recruits Int-6 in NBs. However, it has been reported (Guo and Sen, 2000) that the observed Int-6 localization in PML nuclear bodies is probably not physiological, because the nuclear Int-6 do not have a speckled staining pattern.

The Int-6 gene was originally discovered as one of the integration sites of the murine mammary tumour virus (MMTV), associated with the development of mammary tumours. Virus integration in the Int-6 locus leads to gene disruption resulting in the expression of a truncated form of the protein; this was suggested to be important for virus-induced transformation (Marchetti et al., 1995). An unexpected connection between Int-6 and protein synthesis was made by the observation that the P48 sub-unit of the translation initiation factor eIF-3 is identical to Int-6 (Asano et al., 1997). There have been conflicting reports regarding the sub-cellular location of the Int- 6 protein. It was claimed to be a nuclear protein by one group and a cytoplasmic protein by others (see references in Guo and Sen, 2000). In fact, the protein can exist in both compartments of the cell. Like many eukaryotic shuttle proteins, it has an authentic nuclear localization signal and a nuclear export signal. Interestingly, it has been reported that the interaction of the IFN-induced P56 protein with the cytoplasmic P48/Int-6 sub-unit of eIF3 causes inhibition of translation (Guo and Sen, 2000).

The fact that Int- 6 exhibits the characteristics of a shuttle protein strongly suggests that it could have a nuclear function. However, further analyses will determine the association of Int- 6 to NBs and the importance of the Tax, Int-6 and PML interactions in adult $\mathrm{T}$ leukaemia in patients infected with HTLV-1.

\section{Lymphocytic choriomeningitis virus}

Lymphocytic choriomeningitis virus (LCMV) is a negative-stranded virus in the arenavirus family. Arenavirus encodes five different products: a nucleocapside (NP), an envelope glycoprotein (GP), an RNA polymerase (L) and an $11 \mathrm{kDa}$ Ring finger protein $(\mathrm{Z})$ with an unknown function. It has been shown that $Z$ protein associates with eukaryotic initiation factor $4 \mathrm{E}$ and selectively represses translation in a Ring-dependent manner (Campbell Dwyer et al., 2000). LCMV infection results in redistribution of PML from NBs to the cytoplasm (Borden et al., 1998b). In transfection experiments, $Z$ associates with PML NBs, binds directly to PML and delocalizes it to the cytoplasm. The interaction site in PML is between N-terminal amino-acid 5 and 50 , a region with high proline content. Neither, the Ring finger, B1 or B2 box are involved in the interaction with $\mathrm{Z}$ protein (Borden et al., 1998b).

Although arenavirus replicates in the cytoplasm, the nucleus is required for replication. The viral $\mathrm{Z}$ gene product can be found in the nucleus in association with PML protein and with ribosomal $\mathrm{P}$ proteins (Borden et al., 1998a). Recent studies suggest that PML expression may result in diminished LCMV replication (Djavani et al., 2001), since virus production in $\mathrm{PML}^{-/-} \mathrm{MEF}$ exceeds modestly (fivefold) virus production in $\mathrm{PML}^{+/+}$ MEF, the authors propose that PML reduces LCMV transcription through its interaction with the $\mathrm{Z}$ protein.

\section{Rabies virus}

Rabies virus is a member of the family Rhabdoviridae. Its genome is a $12 \mathrm{~kb}$ negative-stranded RNA which consists of five genes encoding successively the nucleoprotein $(\mathrm{N})$, the phosphoprotein $(\mathrm{P})$, the matrix protein $(\mathrm{M})$, the glycoprotein $(\mathrm{G})$ and the RNA polymerase (L). The genome organization is functionally similar to that of VSV, the prototype of rhabdovirus. It is noteworthy that, in the case of rabies virus, four other amino-terminally truncated products $(\mathrm{P} 2, \mathrm{P} 3, \mathrm{P} 4, \mathrm{P} 5)$ translated from $\mathrm{P}$ mRNA, have been found in purified virus, in infected cells and in cells transfected with a plasmid encoding the complete $\mathrm{P}$ protein. Translation of these proteins is initiated from internal in-frame AUG initiation codons by a leaky scanning mechanism (Chenik et al., 1995). Whereas P and P2 are located in the cytoplasm, P3, P4 and $\mathrm{P} 5$ are found mostly in the nucleus (Chenik et al., 1995). Since the viral cycle takes place in the cytoplasm, this nuclear localization may have a biological effect that remains to be determined. It should be noted that the expression of GFP-P3 in transfected cells shows a distinct speckled nuclear localization, which resembles that of PML. We have shown that infection with rabies virus, but not with VSV, disrupts PML NBs and diminishes the conjugation of PML to SUMO. In transfection experiments, the viral proteins $\mathrm{N}, \mathrm{M}, \mathrm{G}, \mathrm{L}$ have no effect, whereas $\mathrm{P}$ and $\mathrm{P} 3$ are involved in the alteration of PML NBs. P binds directly to PML and delocalizes it from the NBs to the cytoplasm. The importance of NBs reorganization during rabies replication are under investigation (Blondel et al., manuscript in preparation)

\section{Conclusions}

Although the function of PML NBs is still unclear, some observations suggest that they may represent preferential targets for viral infections by members of both DNA and RNA viral families. The PML RBCC/ TRIM motif is essential for PML NBs organization, hetero-interactions, apoptotic and antiviral properties. 
Over-expression of PML (1-641, isoform III) inhibits replication of VSV, influenza virus and HFV. Both the nucleoplasmic and the NB-associated forms of PML confer resistance against these viruses. As far as we know, PML is the first example of an IFN-induced protein that inhibits the function of a viral transactivator through a physical interaction. It could be interesting to determine whether other PML isoforms confer resistance against these viruses and whether other functions attributed to PML (i.e. apoptosis, tumour suppression, senescence) are maintained when PML is no longer localized on NBs. Thus, PML can contribute to the establishment of the antiviral state in IFN-treated cells. The significant inhibitory effect of PML places it in the family of IFN-induced proteins mediating antiviral properties

\section{Abbreviations}

PML, pro-myelocytic leukaemia; APL, acute promyelocytic leukaemia; SUMO, Small Ubiquitin MOdifier; PKR, protein kinase RNA-dependent; IRF, interferon regulatory

\section{References}

Adelson M, Martinand-Mari C, Iacono K, Muto N and Suhadolnik R. (1999). Eur. J. Biochem., 264, 806-815.

Ahn JH and Hayward GS. (2000). Virology, 274, 39-55.

Ahn JH, Brignole EJ and Hayward GS. (1998). Mol. Cell. Biol., 18, 4899-4913.

Ahn JH, Jang WJ and Hayward GS. (1999). J Virol., 73, $10458-10471$

Alcalay M, Zangrilli D, Fagioli M, Pandolfi PP, Mencarelli A, Lo Coco F, Biondi A, Grignani F and Pelicci PG. (1992). Proc. Natl. Acad. Sci. USA, 89, 4840-4844.

Arnheiter H and Meier E. (1990). New Biol., 2, 851-857.

Asano K, Merrick W and Hershey J. (1997). J. Biol. Chem., 272, 23477-23480.

Barnard P and McMillan NA. (1999). Virology, 259, $305-$ 313.

Bell P, Brazas R, Ganem D and Maul G. (2000a). J. Virol., 74, 5329-5336.

Bell P, Lieberman PM and Maul GG. (2000b). J. Virol., 74, $11800-11810$

Bergmann M, Garcia-Sastre A, Carnero E, Pehamberger H, Wolff K, Palese P and Muster T. (2000). J. Virol., 74, $6203-6206$.

Black T, Safer B, Hovanessian A and MG K. (1989). J. Virol., 63, 2244-2251.

Bloch D, Chiche J, Orth D, de la Monte SM, Rosenzweig A and Bloch K. (1999). Mol. Cell. Biol., 19, $4423-4430$.

Bloch DB, de la Monte SM, Guigaouri P, Filippov A and Bloch KD. (1996). J. Biol. Chem., 271, $29198-29204$.

Bloch DB, Nakajima A, Gulick T, Chiche JD, Orth D, de La Monte SM and Bloch KD. (2000). Mol. Cell. Biol., 20, $6138-6446$.

Borden KL, Boddy MN, Lally J, O’Reilly NJ, Martin S, Howe K, Solomon E and Freemont PS. (1995). EMBO J., 14, $1532-1541$

Borden KLB, Campbell Dwyer EJ, Carlile GW, Djavani M and Salvato MS. (1998a). J. Virol., 72, 3819-3826.

Borden KL, Campbell Dwyer EJ and Salvato MS. (1997). FEBS Lett., 418, 30-34. factor; IFN, interferon; ISGs, IFN-stimulated genes; STATs, signal transducers and activators of transcription; NBs, nuclear bodies; ISRE, IFN-stimulated response element; GAS, IFN $\gamma$ - activated site; ISGF3, IFN-stimulated gene factor 3 ; IFNAR1, IFN- $\alpha$ receptor1; IFNAR2, IFN- $\alpha$ receptor2; IFNGR1, IFN- $\gamma$ receptor 1 ; IFNGR2, IFN- $\gamma$ receptor2; EMCV, encephalomyocarditis; VSV, vesicular stomatitis virus; HSV, herpes simplex virus; LCMV, lymphocytic choriomeningitis virus; HTLV-1, human $\mathrm{T}$ cell leukaemia virus type1; HDV, hepatitis delta virus; Tas, transactivator of spumaviruses; HFV, human foamy virus; $\mathrm{HCV}$, hepatitis $\mathrm{C}$ virus; $\mathrm{HPV}$, human papilloma virus; HCMV, human cytomegalovirus; $\mathrm{HCV}$, hepatitis $\mathrm{C}$ virus; LTR, long terminal repeats; IP, internal promoter

\section{Acknowledgments}

We thank Roger Everett and all our colleagues from UPR 9045 of Centre National pour la Recherche Scientifique for comments on the manuscript. This work was supported by grants from CNRS and Association pour la Recherche sur le Cancer.

Borden KLB and Salvato MS. (1998b). J. Virol., 72, $758-$ 766.

Burysek L and Pitha PM. (2001). J. Virol., 75, 2345-2352.

Burysek L, Yeow W, Lubyova B, Kellum M, Schafer S, Huang Y and Pitha P. (1999). J. Virol., 73, 7334-7342.

Cai R, Carpick B, Chun R, Jeang K and Willams B. (2000). Arch. Biochem. Biophys., 373, 361-367.

Campbell Dwyer E, Lai H, MacDonald R, Salvato M and Borden K. (2000). J. Virol., 74, 3293 - 3300.

Carvalho T, Seeler J, Ohman K, Jordan P, Petterson U, Akusjarvi G, Carmo-Fonseca M and Dejean A. (1995). J. Biol. Cell., 131, 45-56.

Cayley PJ, Davies JA, McCullagh KG and Kerr IM. (1984). Eur. J. Biochem., 143, 165-174.

Chebath J, Benech P, Revel M and Vigneron M. (1987). Nature, 330, 587-588.

Chelbi-Alix M and de Thé H. (1999). Oncogene, 18, $935-$ 941.

Chelbi-Alix MK and Pelicano L. (1999). Leukemia, 13, $1167-1174$

Chelbi-Alix MK, Pelicano L, Quignon F, Koken MHM and de Thé H. Regulation of cell growth differentiation and genetics in cancers., Tsiftsoglou AS, Sartorelli AC, Housman DE, Dexter MT (ed). Tumor Biology, 99, 17-27.

Chelbi-Alix MK, Pelicano L, Quignon F, Koken MHM, Venturini L, Stadler M, Pavlovic J, Degos L and de Thé H. (1995). Leukemia, 9, 2027-2033.

Chelbi-Alix MK, Quignon F, Pelicano L, Koken MHM and de The H. (1998). J. Virol., 72, 1043-1051.

Cheng G, Gross M, Brett ME and He B. (2001). J. Virol., 75, $3666-3675$.

Chenik M, Chebli K and Blondel D. (1995). J. Virol., 69, $707-712$.

Coccia EM, Romeo G, Nissim A and Marziali G. (1990). Virology, 179, 228-233.

Daniel MT, Koken M, Romagne O, Barbey S, Bazarbachi A, Stadler M, Guillemin MC, Degos L, Chomienne C and de The H. (1993). Blood, 82, 1858-1867. 
Day M, Roden R, Lowy D and Schiller J. (1998). J. Virol., 72, $142-150$.

Dent AL, Yewdell J, Puvion-Dutilleul F, Koken MHM, de Thé H and Staudt LM. (1996). Blood, 88, 1423-1436.

Der S, Zhou A, Williams B and Silverman R. (1998). Proc. Natl. Acad. Sci., 95, 15623-15628.

Der SD and Lau AS. (1995). Proc. Natl. Acad. Sci., 92, $8841-8845$.

Desbois C, Rousset R, Bantignies F and Jalinot P. (1996). Science, 273, $951-953$.

Diaz-Guerra M, Rivas C and Esteban M. (1997). Virology, 227, 220-228.

Djavani M, Rodas J, Lukashevich IS, Horejsh D, Pandolfi PP, Borden KL and Salvato MS. (2001). J. Virol., 75, 6204-6208.

Dyck JA, Maul GG, Miller Jr WH, Chen JD, Kakizuka A and Evans RM. (1994). Cell, 76, $333-343$.

Everett RD. (1999). Trends Biochem. Sci., 24, 293-295.

Everett RD, Freemont P, Saitoh H, Dasso M, Orr A, Kathoria M and Parkinson J. (1998). J. Virol., 72, 6581 6591.

Fabunmi RP, Wigley WC, Thomas PJ and DeMartino GN. (2001). J. Cell. Sci., 114, 29-36.

Foss GS and Prydz H. (1999). J. Biol. Chem., 274, 3519635202.

Gale Jr M and Katze MG. (1998). Pharmacol. Ther., 78, 29 46.

Gale MJJ, Kwieciszewski B, Dossett M, Nakao H and Katze MG. (1999). J. Virol., 73, 6506-6516.

Gongora C, David G, Pintard L, Tissot C, Hua TD, Dejean A and Mechti N. (1997). J. Biol. Chem., 272, $19457-$ 19463.

Gongora C, Degols G, Espert L, Hua TD and Mechti N. (2000). Nucleic Acids Res., 28, 2333 - 2341.

Goodbourn S, Didcock L and Randall R. (2000). J. Gen. Virol., 81, $2341-2364$.

Grötzinger T, Jensen K and Will H. (1996). J. Biol. Chem., 271, 25253-25260.

Guldner H, Szostecki C, Grotzinger T and Will H. (1992). J. Immunol., 149, 4067-4073.

Gunnery S, Rice AP, Robertson HD and Mathews MB. (1990). Proc. Natl. Acad. Sci., 87, 8687-8691.

Guo J and Sen G. (2000). J. Virol., 74, 1892-1899.

Haller O, Frese M and Kochs G. (1998). Rev. Sci. Tech., 17, $220-230$

Hassel B, Zhou A, Sotomayor C, Maran A and Silverman R. (1993). EMBO J., 12, 3297-3304.

Hatada E, Saito S and Fukuda R. (1999). J. Virol., 73, $2425-$ 2433.

He F, Blair WS, Fukushima J and Cullen BR. (1996). $J$. Virol., 70, 3902-3908.

Heim MH, Moradpour D and Blum HE. (1999). J. Virol., 73, $8469-8475$.

Imani F and Jacobs BL. (1988). Proc. Natl. Acad. Sci., 85, $7887-7891$.

Ishov A, Sotnikov A, Negorev D, Vladimirova O, Neff N, Kamitani T, Yeh E, Strauss III J and Maul G. (1999). J. Cell. Biol., 147, 221-223.

Koken MHM, Puvion-Dutilleul F, Guillemin MC, Viron A, Linares-Cruz G, Stuurman N, de Jong L, Szostecki C, Calvo F, Chomienne C, Degos L, Puvion E and de Thé H. (1994). EMBO J., 13, $1073-1083$.

Kumar R, Choubey D, Lengyel P and Sen GC. (1988). $J$ Virol., 62, $3175-3181$.

Lanotte M, Martin-Thouvenin V, Najman S, Balerini P, Valensi F and Berger R. (1991). Blood., 77, 1080-1086.
Lavau C, Marchio A, Fagioli M, Jansen J, Falini B, Lebon P, Grosveld F, Pandolfi PP, Pelicci PG and Dejean A. (1995). Oncogene, 11, 871-876.

Lecellier CH and Saib A. (2000). Virology, 271, 1-8.

Leonard G and Sen G. (1997). J. Virol., 71, 5095-5101.

Li S, Labrecque S, Gauzzi M, Cuddihy A, Wong A, Pellegrini S, Matlashewski G and Koromilas A. (1999). Oncogene, 18, 5727-5737.

Linial ML. (1999). J. Virol., 73, 1747-1755.

Look D, Roswit W, Frick A, Gris-alevy Y, Dickhaus D, Walter D and Holtzman M. (1998). Immunity, 9, 871-880.

Marchetti A, Buttitta F, Miyazaki S, Gallahan D, Smith G and Callahan R. (1995). J. Virol., 69, 1932-1938.

Martinand C, Montavon C, Salehzada T, Silhol M, Lebleu B and Bisbal C. (1999). J. Virol., 73, 290-296.

Maul G and Everett R. (1994). J. Gen. Virol., 75, 1223 - 1233.

Meier E, Fäh J, Grob MS, End R, Staeheli P and Haller O. (1988). J. Virol., 62, 2386-2393.

Melville MW, Tan SL, Wambach M, Song J, Morimoto RI and Katze MG. (1999). J. Biol. Chem., 274, 3797-3803.

Meurs EF, Watanabe Y, Kadereit S, Barber GN, Katze MG, Chong K, Williams BRG and Hovanessian AG. (1992). J. Virol., 66, 5805-5814.

Meurs EF, McMillan N, William BRG, Hovanessian AG and Southern PJ. (1995). Virology, 214, 653-659.

Miller D, Rahill B, Boss J, Lairmore M, Durbin J, Waldman J and Sedmak D. (1998). J. Exp. Med., 187, 675-683.

Miller D, Zhang Y, Rahill B, Waldman W and Sedmak D. (1999). J. Immunol., 162, 6107-6113.

Morris-Desbois C, Bochard V, Reynaud C and Jalinot P. (1999). J. Cell. Sci., 112, $3331-3342$.

Muller S and Dejean A. (1999). J. Virol., 73, 5137-5143.

Nason-Burchenal K, Gandini D, Botto M, Allopenna J, Seale JRC, Cross NCP, Goldman JM, Dmitrovsky E and Pandolfi PP. (1995). Blood, 88, 3926-3936.

Nguyen L, Espert L, Mechti N and Wilson D. (2001). Biochemistry, 40, 7174-7179.

Pavlovic J, Zurcher T, Haller O and Staeheli P. (1990). J. Virol., 64, 3370-3375.

Pelicano L, Brumpt C, Pitha PM and Chelbi-Alix MK. (1999). Oncogene, 18, 3944-3953.

Pellegrini S and Dusanter-Fourt I. (1997). Eur. J. Biochem., 248, 615-633.

Pfeffer LM, Dinarello CA, Herberman RB, Williams BRG, Borden EC, Borden R, Walter MR, Nagabhushan TL, Trotta PP and Pestka S. (1998). Cancer Res., 58, 2489 2499.

Pine R, Canova A and Schindler C. (1994). EMBO J., 13, $158-167$.

Player MR and Torrence PF. (1998). Pharmacol. Ther., 78, $55-113$.

Poppers J, Mulvey M, Khoo D and Mohr I. (2000). J. Virol., 74, 11215-11221.

Puvion-Dutilleul F, Chelbi-Alix M, Koken M, Quignon F, Puvion E and de The H. (1995). Exp. Cell. Res., 218, 9-16.

Puvion-Dutilleul F, Legrand V, Mehtali M, Chelbi-Alix MK, de Thé H and Puvion E. (1999). Biol. Cell, 91, $617-$ 628.

Rechsteiner M, Realini C and Ustrell V. (2000). Biochem. J., 345, $1-15$.

Regad T, Saib A, Lallemand-Breitenbach V, Pondolfi PP, de The $\mathrm{H}$ and Chelbi-Alix MK. (2001). EMBO J., 20, $3495-$ 3505 .

Schindler C and Darnell JEJ. (1995). Annu. Rev. Biochem. 64, $621-651$ 
Schroder H, Ugarkovic D, Merz H, Okamoto T and Muller W. (1990). FASEB J., 4, 3124-3130.

Sen GC and Ransohoff RM. (1993). Adv. Virus Res., 42, $57-$ 102.

Sharp T, Schwemmle M, Jeffrey I, Laing K, Mellor H, Proud G, Hilse K and Clemens M. (1993). Nucleic Acids Res., 21, $4483-4490$.

Sharp TV, Moonan F, Romashko A, Joshi B, Barber GN and Jagus R. (1998). Virology, 250, 302-315.

Sharp TV, Witzel JE and Jagus R. (1997). Eur. J. Biochem., 250, $85-91$.

Stadler M, Chelbi-Alix MK, Koken MHM, Venturini L, Lee C, Saïb A, Quignon F, Pelicano L, Guillemin M-C, Schindler C and de Thé H. (1995). Oncogene, 11, 25652573.

Staeheli P, Pitossi F and Pavlovic J. (1993). Trends Cell. Biol., 3, 268-272.

Stark GR, Kerr IM, William BRG, Silverman RH and Schreiber RD. (1998). Annu. Rev. Biochem., 67, 227-264.

Sternsdorf T, Grotzinger T, Jensen K and Will H. (1997). Immunobiology, 198, 307-331.

Szekely L, Pokrovskaja K, Jiang W, de The H, Ringertz N and Klein G. (1996). J. Virol., 70, $2562-2568$.

Tanahashi N, Yokota K, Ahn J, Chung C, Fujiwara T, Takahashi E, DeMartino G, Slaughter C, Toyonaga T, Yamamura K, Shimbara N and Tanaka K. (1997). Genes Cells, 2, 195-211.

Taylor DR, Shi ST, Romano PR, Barber GN and Lai MM. (1999). Science, 285, 107-110.
Testa U, Grignani F, Barberi T, Fagioli M, Masciulli R, Ferrucci PF, Seripa D, Camagna A, Alcalay M, Pelicci PG and Peschle C. (1994). Cancer Res., 54, 4508-4515.

Wang ZG, Ruggero D, Ronchetti S, Zhong S, Gaboli M, Rivi R and Pandolfi PP. (1998a). Nature Genet., 20, $266-$ 272.

Wang ZG, Delva L, Gaboli M, Rivi R, Giorgio M, CordonCardo C, Grosveld F and Pandolfi PP. (1998b). Science, 279, $1547-1551$.

Weis K, Rambaud S, Lavau C, Jansen J, Carvalho T, Carmo-Fonseca M, Lamond A and Dejean A. (1994). Cell, 76, 345-356.

Yang YL, Reis LF, Pavlovic J, Aguzzi A, Schafer R, Kumar A, Williams BR, Aguet $M$ and Weissmann C. (1995). EMBO J., 14, 6095-6106.

Zhou A, Paranjape J, Brown TL, Nie H, Naik S, Dong B, Chang A, Trapp B, Fairchild R, Colmenares C and Silverman RH. (1997). EMBO J., 16, 6355-6363.

Zhou A, Paranjape J, Der S, Williams B and Silverman R. (1999). Virology, 258, 435-440.

Zimring J, Goodbourn S and Offermann M. (1998). J. Virol., $701-707$.

Zürcher T, Pavlovic J and Staeheli P. (1992a). Virology, 187, $796-800$.

Zürcher T, Pavlovic J and Staeheli P. (1992b). J. Virol., 66, $5059-5066$. 